\title{
DOMINANCE OF THE MULTICOLOURED ASIAN LADY BEETLE HARMONIA AXYRIDIS IN AN UNDISTURBED WILD MEADOW ECOSYSTEM
}

\author{
ÉLISE BÉLANGER*AND ÉRIC LUCAS
}

Laboratoire de lutte biologique, Département des Sciences Biologiques, Université du Québec à Montréal, C.P. 8888 Succ. Centre-ville, Montréal, Québec, Canada H3C 3P8, Tel (514) 987-3000 (4799\#), Fax: (514) 987-4647

*Corresponding author: belanger.elise.3@courrier.uqam.ca

\section{ABSTRACT}

Fifteen years after its arrival in Quebec (Canada), the multicoloured Asian lady beetle Harmonia axyridis (Pallas 1773) (Coleoptera: Coccinellidae) has become one of the dominant coccinellid species in agricultural, forested and urban areas. Several studies conducted in North American agricultural ecosystems show that the arrival of $H$. axyridis and other exotic coccinellid species was followed by decreases in the populations of native coccinellid species. In this study, the abundances of $H$. axyridis and other native and exotic species were determined in an undisturbed wild meadow located in a protected area. In 2009 and 2010, mainly Solidago canadensis L. (Asteraceae) and Asclepias syriaca L. (Asclepiadaceae) infested with aphids were surveyed. A total of 1522 individuals, belonging to seven different species, were recorded. In 2009, on all the plants monitored, H. axyridis was clearly the dominant species (69\% of the coccinellid assemblage). In addition, this exotic species constituted $84 \%$ of the coccinellid assemblage, including Propylea quatuordecimpunctata (L.) and Coccinella septempunctata (L). It is likely the dominance of the eurytopic Asian lady beetle in agricultural, forested, urban and undisturbed open ecosystems, poses a threat to native lady beetles. These results also provide evidence that undisturbed wild meadow ecosystems will not constitute a natural refuge from Harmonia axyridis for native species of lady beetles.

Keywords: Coccinellidae, exotic species, native species, refuge, Solidago canadensis, Asclepias syriaca

\section{Introduction}

The destruction of habitats and establishment of invasive species are matters of concern, for the conservation of global diversity (Pimentel et al. 2000; Vitousek et al. 1997). Some studies conducted in North American agricultural ecosystems show that the arrival of exotic species of coccinellid was followed by declines in the numbers of native species (Brown 2003; Turnock et al. 2003; Alyokhin and Sewell 2004; Evans 2004). However, the consequences of successful establishment of exotic species are still poorly known (Soares et al. 2007; Koch and Galvan 2008). A review of multi-year surveys of coccinellid populations (Harmon et al. 2007) indicated it is difficult to conclude that exotic species have had a negative effect on the abundance of native species, due mainly to the high variability in coccinellid population densities from year to year. Nevertheless, changes in coccinellid assemblage and declines in the abundances of some native species in different ecosystems are recorded. In Eastern Canadian agricultural systems exotic lady beetles are dominant (up to $89 \%$ of the coccinellids encountered) and since their arrival, Hippodamia tredecimpunctata tibialis (Say), a previously common native species, has almost disappeared from these habitats (Lucas et al. 2007a).

The Asian lady beetle Harmonia axyridis (Pallas) has been particularly well studied in the past few years. Because $H$. axyridis is an effective generalist predator of aphids it has been repeatedly introduced into countries throughout the world for biological control purposes. In North America, this species was introduced in 1916 (Gordon 1985), first became established in Louisiana in 1988 and first recorded in Quebec (Canada) agroecosystems in 1994 (Coderre et al. 1995). Eastern Canadian agroecosystems were invaded previously by two exotic coccinellid species, Propylea quatuordecimpunctata L., in the 1960s (Gordon 1985) and Coccinella septempunctata L. in 1973 (Larochelle 1979). However, only ten years after the arrival of $H$. axyridis it became one of the dominant exotic species in most perennial and annual crops (5 to $64 \%$ of the coccinellids encountered) in Eastern Canada (Lucas et al. 2007a). This species is also recorded in many types of ecosystems like areas forested with aspen, birch, willow and fir (Berthiaume et al. 2000) and even in urban areas (Labrie et al. 2008). Many developmental and behavioural traits of this species may have contributed to its invasive success. Compared to the indigenous Coleomegilla maculata lengi Timberlake (Coleoptera: Coccinellidae) the larvae of $H$. axyridis develop faster, are more voracious and search more efficiently, which may account for its invasiveness in Eastern Canada (Labrie et al. 2006).

Some negative effects of introducing exotic species are reported: competitive suppression, competitive displacement of native natural enemies and suppression of non-target prey species (Simberloff and Stiling 1996; Williamson 1996; Alyohin and Sewell 2004; Evans 2004). 
Competitive displacement is defined, as "the removal of a formerly established species from a habitat through superior use, acquisition, or defence of resources by another species" (Reitz and Trumble 2002). Related to this competitive response, some authors refer to the Habitat compression hypothesis (Evans 2000; Evans 2004; Alyokhin and Sewell 2004; Finlayson et al. 2008; Gardiner et al. 2009; Kajita and Evans 2009) and speculate that native species retreat and remain dominant in non-agricultural habitats in response to the arrival of exotic lady beetles. Habitat compression could be the result of either exploitative competition, when exotic species significantly reduce aphid populations in agricultural habitats, or of intraguild predation of native ones by invasive species. Evans (2000) found that even though C. septempunctata is broadly distributed across the agricultural landscapes in Utah (USA), it is not as dominant in natural habitats (3\% of the total assemblage), where Coccinella tranversoguttata Faldermann and other native species are dominant. It is possible, however, that exotic species may spread less rapidly in un-fragmented landscapes and that the complexity of some communities acts as a buffer against invasion (Tilman 1997; Sakai et al. 2001).

The aim of the present study was to characterize the coccinellid assemblage in an undisturbed wild meadow ecosystem and evaluate whether it is dominated by exotic or native species. Based on the study of Evans (2000; 2004) it was postulated that native species would numerically dominate $H$. axyridis and other exotic lady beetles. If this is the case then it would signify that undisturbed natural ecosystems may act as refuges for native lady beetles.

\section{Material and Methods}

\section{Study site}

This research was conducted on Saint-Bernard Island $\left(45^{\circ} 23^{\prime} \mathrm{N}, 73^{\circ} 45^{\prime} \mathrm{O}\right)$, a protected area $30 \mathrm{~km}$ south-west of Montreal (Quebec, Canada) (Fig. 1). The island, located on the Saint-Louis Lake, consists of 250 hectares of several different ecosystems edged on south and east shores by the Chateauguay River (50 to $100 \mathrm{~m}$ wide). For this study, the wild meadow ecosystem, which makes up approximately on third of the island, was surveyed. The dominant vegetation in this ecosystem consisted of the following species: Asclepias syriaca L. (Asclepiadaceae), Solidago canadensis L. (Asteraceae), Crataegus spp. L. (Rosaceae), Verbascum thapsus L. (Scrophulariaceae), Achillea millefolium L. (Asteraceae), Vicia cracca L. (Fabaceae), Linaria vulgaris Miller (Scrophulariaceae), Brassica kaber (DeCandolle) (Brassicaceae), Rhus typhina L. (Anacardiaceae), Vitis riparia Michx (Vitaceae), Cirsium arvense L. Scopoli (Asteraceae) and Phragmites australis (Cav.) Trin. ex Steud. (Poaceae) (Héritage Saint-Bernard 2004).

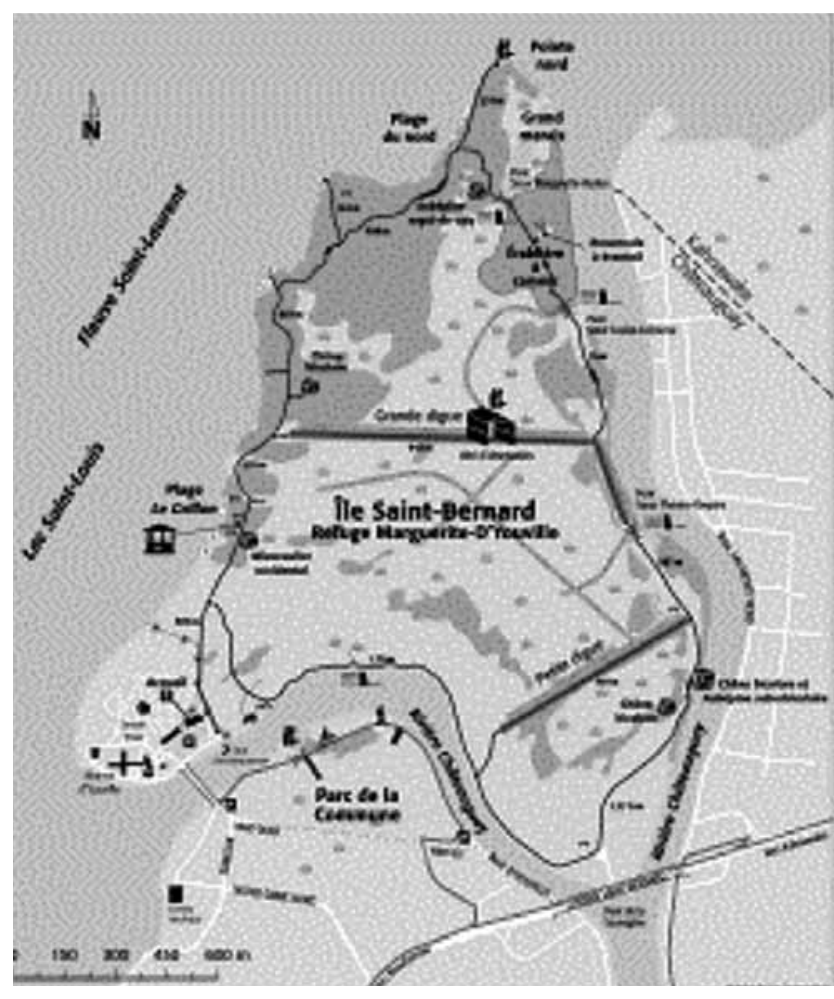

Fig. 1 Saint-Bernard Island $45^{\circ} 23^{\prime} \mathrm{N}, 73^{\circ} 45^{\prime} \mathrm{O}$ (Québec, Canada) (Héritage Saint-Bernard 2004).

\section{Plant species}

The survey was conducted mainly on S. canadensis infested with aphids (Hemiptera: Aphididae). This species was selected because it is very common throughout summer. Furthermore, several different species of aphids are commonly found on these plants: Uroleucon nigrotuberculatum (Olive) and Uroleucon caligatum (Richards). There were also other plants infested with aphids: A. syriaca, $P$. australis and C. arvense, and these species were also included in the 2009 survey. In 2010 only S. canadensis was surveyed because there was a great density and diversity of coccinellids on this plant species.

\section{Sampling}

The wild meadow was surveyed weekly from May to October in 2009 and 2010. Depending on the sampling period, up to five samples of 50 plants in the same area of each species of host plant were selected. The plants chosen were infested with aphids (colonies of more than 50 aphids). Species, development stage and abundance of the different coccinellids were recorded by visual observation.

\section{Statistical analysis}

Although all the coccinellid species observed were recorded, the analysis was limited to aphidophagous lady beetles. Two species were excluded from the analysis (Psyllobora vigintimaculata (Say) and Chilocorus 


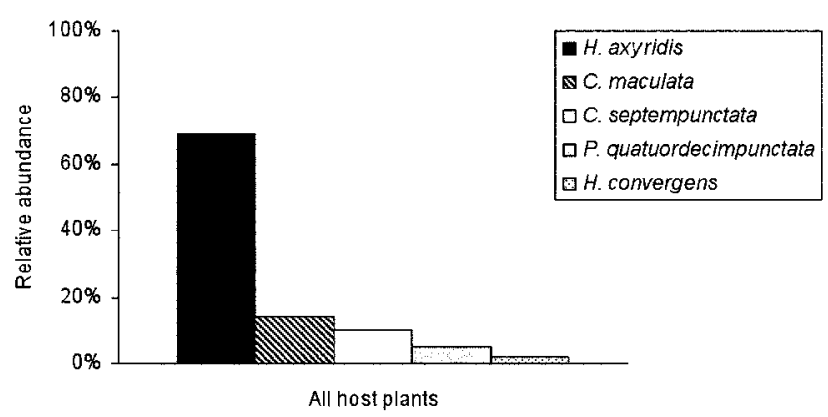

Fig. 2 Percentage relative abundance of five species of coccinellids on the plants sampled in 2009.

stigma Say) as only a few individuals were found on the host plants surveyed. The data collected throughout the season were pooled for each host plant. To compare the relative percentages of the different species and the proportion of invasive versus indigenous species in the two years (2009-2010) on S. canadensis, a contingency table (G test) was used. For the same year (2009), the nonparametric Wilcoxon matched-pairs signed-ranks test was used to compare the different species and coccinellid origin (exotic vs.native) per host plant, as coccinellid abundance was not normally distributed. Analyses were performed using JMP 7.0.1 (SAS Institute 2007).

\section{Results}

All host plants: A total of 1255 coccinellids were observed in 2009 and 267 in 2010 (only on S. canadensis). Seven different species were recorded, including the exotic $P$. quatuordecimpunctata, C. septempunctata and H. axyridis and the indigenous C. maculata and Hippodamia convergens Guérin-Méneville. Considering the results for all the host plants in 2009, H. axyridis was the dominant species (69\% of the total coccinellid assemblage), followed by C. maculata (14\%) (Fig. 2). Exotic species made up $84 \%$ of the coccinellid assemblage and C. septempunctata and P. quatuordecimpunctata account, respectively, for $10 \%$ and $5 \%$. The native coccinellid $H$. convergens made up only $2 \%$ of the total assemblage.

Table 1 Significance of the difference in the numbers of $H$. axyridis and other species of coccinellid recorded in 2009 and 2010 on different plants infested with aphids.

\begin{tabular}{|c|c|c|c|c|c|}
\hline Year & Host plant & $\mathbf{N}$ & Coccinellid species & $Z^{a}$ & $\mathbf{p}^{\mathbf{a}}$ \\
\hline \multirow[t]{4}{*}{2009} & S. canadensis & 32 & H. axyridis - P. quatuordecimpunctata & 245 & $<0.0001^{*}$ \\
\hline & & & H. axyridis - C. maculata & 144.5 & $0.0015^{*}$ \\
\hline & & & H. axyridis - C. septempunctata & 177 & $0.0003^{*}$ \\
\hline & & & H. axyridis - H. convergens & 248 & $<0.0001^{*}$ \\
\hline \multirow[t]{4}{*}{2010} & S. canadensis & 27 & H. axyridis - P. quatuordecimpunctata & 134.5 & $<0.0001^{*}$ \\
\hline & & & H. axyridis - C. maculata & 175.5 & $<0.0001^{*}$ \\
\hline & & & H. axyridis - C. septempunctata & 114 & $0.0020^{*}$ \\
\hline & & & H. axyridis - H. convergens & 175.5 & $<0.0001^{*}$ \\
\hline \multirow[t]{4}{*}{2009} & A. syriaca & 26 & H. axyridis - P. quatuordecimpunctata & 138 & $<0.0001^{*}$ \\
\hline & & & H. axyridis - C. maculata & 138.5 & $<0.0001^{*}$ \\
\hline & & & H. axyridis - C. septempunctata & 147.5 & $<0.0001^{*}$ \\
\hline & & & H. axyridis - H. convergens & 150 & $<0.0001^{*}$ \\
\hline \multirow[t]{4}{*}{2009} & P. australis & 15 & H. axyridis - P. quatuordecimpunctata & 60 & $<0.0001^{*}$ \\
\hline & & & H. axyridis - C. maculata & 60 & $<0.0001^{*}$ \\
\hline & & & H. axyridis - C. septempunctata & 60 & $<0.0001^{*}$ \\
\hline & & & H. axyridis - H. convergens & 60 & $<0.0001^{*}$ \\
\hline \multirow[t]{4}{*}{2009} & C. arvense & 4 & H. axyridis - P. quatuordecimpunctata & 5 & $0.1250-$ \\
\hline & & & H. axyridis - C. maculata & 5 & $0.1250-$ \\
\hline & & & H. axyridis - C. septempunctata & 3 & $0.2500-$ \\
\hline & & & H. axyridis - H. convergens & 5 & $0.1250-$ \\
\hline
\end{tabular}

${ }^{a} \mathrm{Z}$ and $\mathrm{p}$ values are the results of Wilcoxon matched-pairs signed-rank test. Note: * indicates a significant difference between the numbers of the two species

S. canadensis: This host plant was surveyed in 2009 and 2010. The number of native lady beetles recorded in the two years differed greatly. In 2009, $23 \%$ of the assemblage was composed of native species compared to $0.3 \%$ in 2010. The relative percentage of the different species in the coccinellid assemblage changed significantly from
2009 to 2010 (G test: $\left.G_{5}=195.76 ; p<0.0001\right)$ as did the relative percentage of invasive versus indigenous species ( $\mathrm{G}$ test: $\mathrm{G}_{1}=34.637 ; \mathrm{p}<0.0001$ ).

In 2009,462 coccinellids were recorded. $H$. axyridis was the dominant coccinellid making up $50 \%$ of the total coccinellid assemblage and was significantly more abun- 


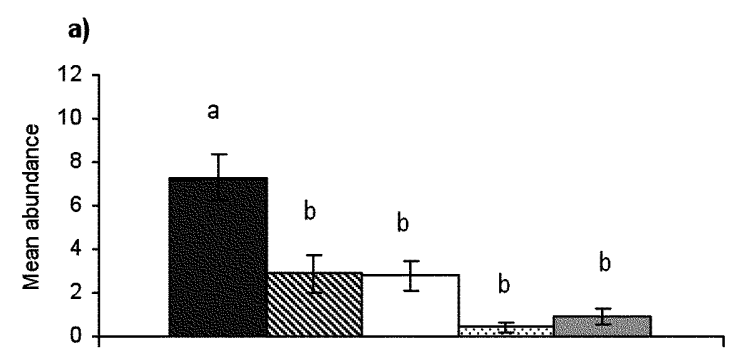

S. canadensis

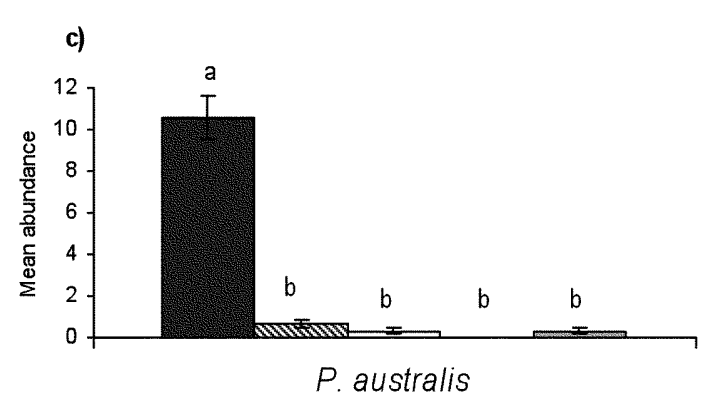

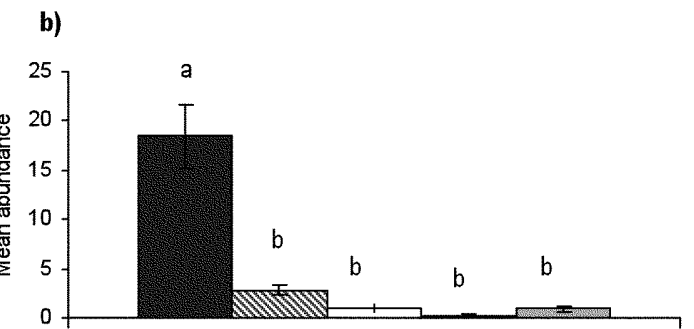

A. syriaca

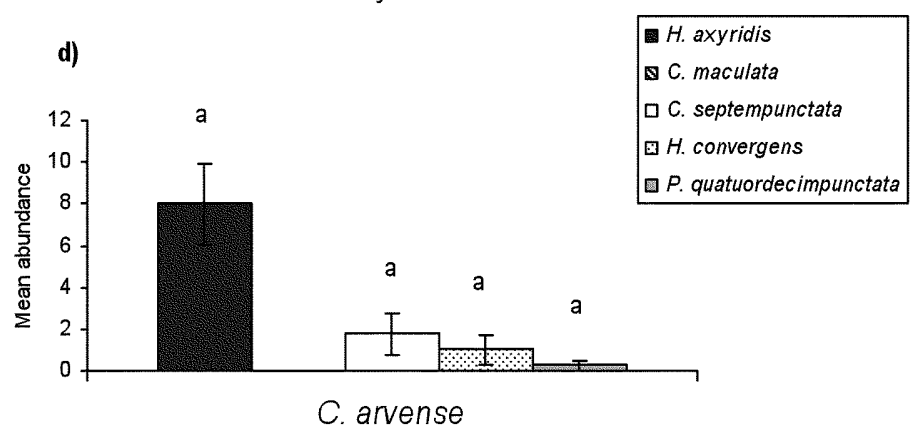

Fig. 3 Abundance (mean \pm SE) of each of the five species of coccinellid recorded on a) S. canadensis, b) A. syriaca, c) P. australis and d) C. arvense in 2009. Different letters indicate a significant difference in the mean abundance of $H$. axyridis compared to each of the other species $(p<0.05)$.

dant than any other species (Table 1 and Fig. 3). The highest percentage of $H$. axyridis was recorded on July 7 th, when it made up $79 \%$ of the coccinellid assemblage, and the lowest percentage on August 19th, when it made up $21 \%$ of the assemblage (Fig. 4). On four different occasions during the sampling season (July 23rd, August 19th, Sept. 10th and 17th) H. axyridis was not the dominant species. Coleomegilla maculata and C. septempunctata were the second and third most dominant exotic species making up, respectively, $20 \%$ and $19 \%$ of the total coccinellid assemblage. The comparison of the numbers of exotic vs. native species revealed that the exotic species were significantly more abundant (Wilcoxon matchedpairs signed-ranks test: S. canadensis 2009: $\mathrm{Z}=195.5$; $\mathrm{N}=32 ; \mathrm{p}<0.0001$ ) (Fig. 6).

In 2010, 267 coccinellids were recorded. $H$. axyridis was the dominant coccinellid making up $67 \%$ of the total coccinellid assemblage and significantly more abundant than any other species (Table 1 and Fig. 3). The highest percentage of $H$. axyridis was recorded on September 21 st, when it made up $100 \%$ of the coccinellid assemblage, and the lowest percentage on July 29th, when it made up $32 \%$ of the assemblage (Fig. 4 ). On two different occasions during the sampling season (July 14th and 29th) $H$. axyridis was not the dominant species. Coccinella septempunctata and P. quatuordecimpunctata were the second and third most dominant exotic species, making up, respectively, $18 \%$ and $15 \%$ of the total coccinellid assemblage. Hippodamia convergens, a native species, was not recorded. The comparison of the numbers of exotic vs. native species revealed that exotic species were significantly more abundant (Wilcoxon matched-pairs signed-ranks test: S. canadensis 2010: $\mathrm{Z}=189 ; \mathrm{N}=27$; $\mathrm{p}<0.0001$ ) (Fig. 6).
A. syriaca: When this plant was surveyed in 2009 a total of 587 coccinellids were recorded. Harmonia axyridis was the dominant coccinellid making up $78 \%$ of the total assemblage and was significantly more abundant that any other species (Table 1 and Fig. 3). The highest percentage of $H$. axyridis was recorded on August 19th, when it made up $85 \%$ of the coccinellid assemblage, and the lowest percentage on July $23 \mathrm{rd}$, when it made up $43 \%$ of the assemblage (Fig. 5). Harmonia axyridis was the more abundant species recorded throughout the sampling season. Coleomegilla maculata was the second most dominant species making up $12 \%$ of the total coccinellid assemblage. The comparison of the numbers of exotic vs. native species revealed that the exotic species were significantly more abundant (Wilcoxon matched-pairs signedranks test: $Z=152 ; N=26 ; p<0.0001$ ) (Fig. 6).

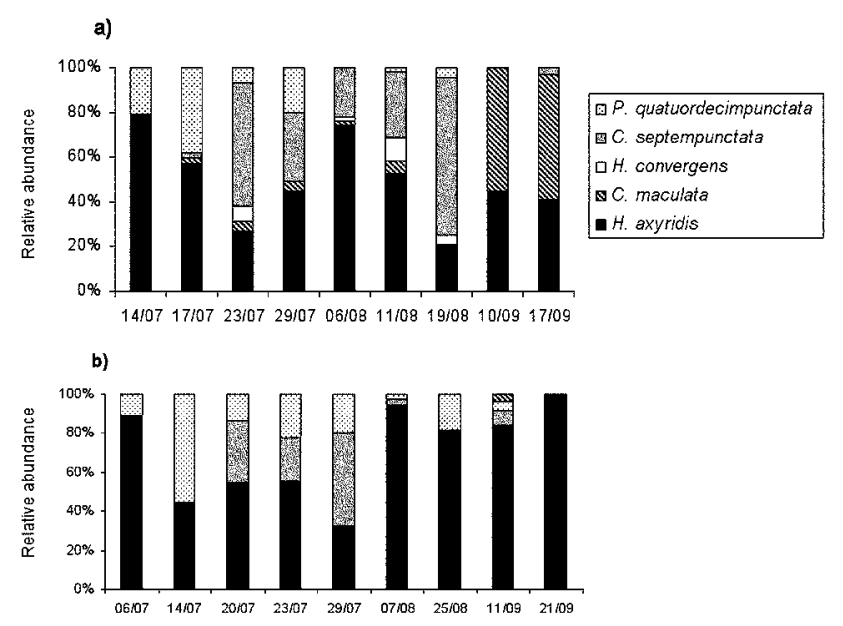

Fig. 4 Percentage relative abundance of each of the five species of coccinellid recorded each week on S. canadensis in a) 2009 and b) 2010. 


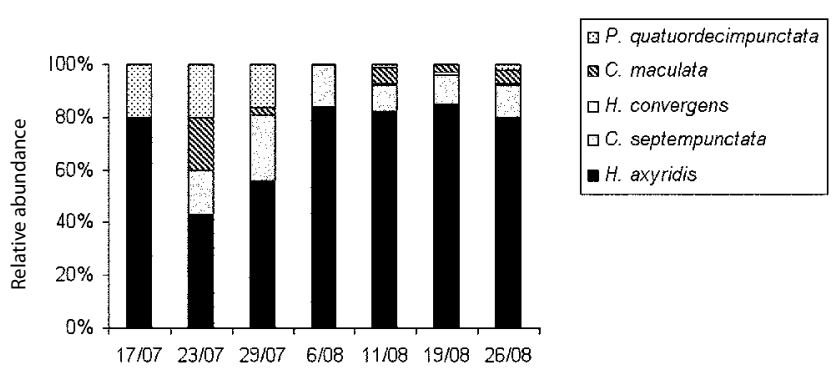

Fig. 5 Percentage relative abundance of the five species of coccinellid recorded each week on A. syriaca in 2009.

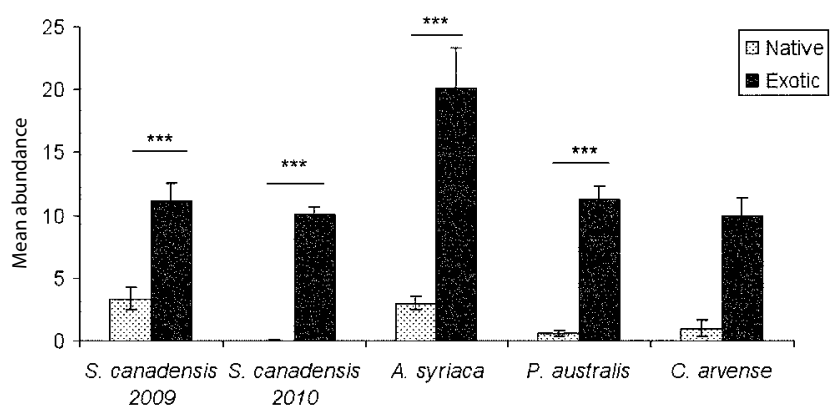

Fig. 6 Abundance (mean $\pm S E$ ) of exotic and native lady beetles recorded on different host plants in 2009 and 2010. Note: * indicates $p<0.05,{ }^{* *} p<0.01,{ }^{* * *} p<0.001$.

P. australis and C. arvense: These species were surveyed in 2009. Aphids and coccinellids were mainly recorded on $P$. australis from the end of July to mid-August. Of the 140 coccinellids recorded, $H$. axyridis was the dominant coccinellid making up $88 \%$ of the total assemblage and was significantly more abundant than any other species (Table 1 and Fig. 3). The comparison of the numbers of exotic vs. native species revealed that the exotic species were significantly more abundant (Wilcoxon matched-pairs signed-ranks test: $Z=60 ; N=15$; $\mathrm{p}<0.0001$ ) (Fig. 6).

Aphids and coccinellids were mainly recorded on C. arvense from the end of September to the beginning of October. Of the 46 coccinellid recorded, $H$. axyridis was the dominant species making up $67 \%$ of the total assemblage. Coccinella septempunctata (15\% of the assemblage) and $H$. convergens ( $13 \%$ of the assemblage) were the second and third most dominant species.

\section{Discussion}

In the undisturbed wild meadow system, exotic species were more abundant than native species, on all the species of plants surveyed. Furthermore, the multicoloured Asian lady beetle numerically dominated the coccinellid assemblages. That is, these results do not support the hypothesis that native species of coccinellids are likely to numerically dominate exotic species in natural habitats. According to the considerable difference between exotic and native populations, there is also no evidence that native lady beetles have retreated to non-agricultural habitats in response to the arrival of exotic lady beetles.

In the United States, studies on the abundance of native and exotic coccinellids have revealed similar results. Finlayson et al. (2008), in a study conducted at different locations in Maine (agricultural and non-agricultural habitats), found that native lady beetles abundance was never higher than that of exotic species in any habitat. Furthermore, there was a strong correlation between native and exotic lady beetle abundances in terms of habitat preference. In another study, Gardiner et al. (2009) compared the density of lady beetles recorded in different types of landscape (forest and grassland) surrounding soybean fields in Iowa, Michigan, Minnesota and Wisconsin. At all locations, exotic lady beetles were more abundant than native species. However, $H$. axyridis was more abundant in forested landscape and native species ( $H$. convergens and C. maculata) most numerous in grassland habitats. These authors discuss the possibility that different types of perennial grassland, such as pasturelands, restored meadows and abandoned old fields may better support native species. In the current study, the presence of forested area near the wild meadow could have favoured arboreal lady beetles such as $H$. axyridis. Nevertheless, there was not a higher percentage of native species in the wild meadow. Furthermore, there was a higher percentage of exotic species in this wild meadow than in many agricultural habitats in Eastern Canada (Lucas et al. 2007a). This is in contrast with the findings of Evans $(2000 ; 2004)$, where the native species still dominated a native riparian habitat but declined in alfalfa fields, invaded by the exotic species, C. septempunctata. However, these studies differ in certain respects: 1) The state of Utah (USA) where Evans conducted his research is very different in terms of ecosystem and climatic conditions from Eastern Canada (the present study) and the state of Maine (USA) (Finlayson et al. 2008); 2) The main invader in the two studies differed. In the study of Evans, C. septempunctata was the most abundant exotic lady beetle, which in the current study made up only $10 \%$ of the total assemblage dominated by $H$. axyridis, which was not present in the system studied by Evans. In fact, $H$. axyridis appears to be very aggressive and is reported as an intraguild predator of C. septempunctata (Hironori and Katsuhiro 1997; Yasuda et al. 2004; Ware and Majerus 2007). Consequently, the invasion by $H$. axyridis resulted in many cases of C. septempunctata being displaced from its dominant position (Brown and Miller 1998; Turnock et al. 2003; Alhmedi et al. 2010); 3) Invasion is a dynamic process. At the time of the surveys by Evans (2000; 2004), C. septempunctata may not have spread to unperturbed habitats (Finlayson et al. 2008). It would be interesting to look at the current situation of C. septempunctata and other exotic species in Utah.

It is clear from the present study, that fifteen years after its arrival in Eastern Canada, the multicoloured 
Asian lady beetle is well established in most types of ecosystems, including undisturbed areas. In fact, this exotic species was recorded on all the plants sampled and on many other plants infested with aphids. Harmonia axyridis was abundant in 2009 and produced several generations at different times on different hosts. For example, at the beginning of the summer there were hundreds of larvae on willows, feeding on chrysomelid larvae. The great ability of this species to feed and reproduce successfully under an array of different conditions, in an array of different habitats may have facilitated the rapid expansion of the range of this invader in North America. Genetic polymorphism, short development time, high fecundity and low susceptibility to pathogens are some of the important traits that may be involved in this process (Soares et al. 2007; Alhmedi et al. 2010). As the Asian lady beetle has come to dominate agricultural, forest, urban and undisturbed open ecosystems in Eastern Canada we are wondering what will stop the expansion of this exotic lady beetle. In Eastern Canada, the climatic conditions and the landscape structure are usually not suitable for outdoor overwintering of $H$. axyridis. However, the presence of houses has allowed its northern geographical expansion, as these refuges provide cold-free space (Labrie et al. 2008). In this context, it is postulated that the $50^{\circ}$ parallel in Eastern Canada will constitute an approximate northern limit for this species, since above this limit, cities are scarce and distant one from each other, and isolated houses relatively rare in the landscape.

The establishment of the eurytopic and polyphagous Asian lady beetle in new environments may generate some positive and negative effects. First, the survival of native lady beetles and other species is a matter of concern, as they may be threatened. The results presented indicate that even though the exotic species were an important part of the coccinellid assemblage in 2009, C. maculata, a native species, was the second most dominant species (14\% of the total assemblage). Although C. maculata has a lower predation and searching efficiency than $H$. axyridis (Labrie et al. 2006), this species seems to be less affected by the invasion of the Asian lady beetle compared to other native species (Cottrell and Yeargan 1998). In fact, the abundance of this native coccinellid could be the result of niche partitioning, since C. maculata is usually restricted to the lower parts of plants and so avoids competition with $H$. axyridis, which is mainly found on the upper parts (Musser and Shelton 2003; Hoogendoorn and Heimpel 2004; Lucas et al. 2007a). For example, in 1978, C. maculata made up $24 \%$ of the coccinellid assemblage in southern Quebec cornfields (Coderre, unpubl. data). Thirty years later, this species is still one of the dominant species, making up 8 to $74 \%$ of the coccinellids recorded in different agricultural ecosystems in Eastern Canada (Lucas et al. 2007a). Nevertheless, other native species seem to be more affected by the presence of $H$. axyridis, then $C$. maculata. The high mobility, large size, aggressive behaviour and better searching efficiency of
H. axyridis may promote its success in different types of interactions (Pell et al. 2007; Soares et al. 2007). Intraguild predation (Michaud 2002; Yasuda et al. 2004) and exploitative competition (Evans 2004) are the two main ecological mechanisms likely to have resulted in the local extinction or displacement of native species. A review of 24 studies on the effect of $H$. axyridis on competitors, indicates that more than half reported a negative effect (Lucas et al. 2007b; Soares et al. 2007). For example, in North America H. axyridis appears to have had a negative effect on the abundance of the following native species: Brachiacantha ursina F., Chilocorus stigma Say and Cycloneda munda Say (Brown and Miller 1998). Moreover in Japan, $H$. axyridis, is a native species, and has limited the establishment of the exotic Adalia bipunctata (L.) (Sakuratani et al. 2000; Kajita et al. 2006). This generalist predator may also attack other natural enemies when target prey are unavailable or scarce and potentially reduce guild diversity. For example, $H$. axyridis feeds on various stages of predatory species, such as Chrysoperla carnea Stephens and Aphidoletes aphidimyza Rondani (Phoofolo and Obrycki 1998; Gardiner and Landis 2007), but currently it is not clear whether $H$. axyridis has a negative effect on the abundance of these species (Brown 2003). Furthermore, $H$. axyridis also preys upon the eggs and larvae of the protected monarch butterfly (Danaus plexippus L.) (Koch et al. 2003). Finally, another consequence of the dominance of $H$. axyridis, is its effect on different pest species: aphids, mites, chrysomelid larvae, etc. A review of 27 studies on $H$. axyridis as a biocontrol agent indicates that it has been effective in controlling 16 different pest species (Lucas et al. 2007b; Soares et al. 2007). For example, there has been a significant decline in the abundance of aphids in many crops since the arrival of the exotics C. septempunctata and H. axyridis (Alyokhin et al. 2004; Evans 2004). This diminution in prey density in agricultural habitats could indirectly affect the relative abundance of the different species, especially native species (Evans and Youssef 1992; Evans 2004). In the present study, there was a considerable difference in the number of native lady beetles on $S$. canadensis in the two years, with only one individual found in 2010 . This may be due to the marked difference in the weather and aphid densities in the two years (warmer summer, with lower aphid densities in 2010). Regarding this research, it is difficult to account for the differences in the relative abundance of the natives and long-term studies are clearly needed to determine whether $H$. axyridis will expand further into other habitats, and whether it will thereby affect other native species.

\section{Conclusion}

Based on the present study, there is no evidence that undisturbed ecosystems would serve as natural refuges for native lady beetles. According to some authors, few 
communities are impenetrable to invasion by exotic species (Usher 1988; Lodge 1993). The disturbance of natural communities by human activities may lead to successful colonization by exotic species, especially reduction in habitat complexity (Simberloff 1989; Vitousek et al. 1996; Reitz and Trumble 2002). Consequently, fragmented and perturbed habitats are often more susceptible to invasion. For example, extensive and repeated releases of $H$. axyridis in several agricultural habitats may have contributed to its success (Soares et al. 2007). However, at a large time scale, some eurytopic and polyphagous exotic lady beetles, such as $H$. axyridis, may colonize most types of ecosystems, including undisturbed ones. For the development of more effective conservation strategies a better understanding of the mechanisms and the lag period observed during the invasion process is required.

\section{Acknowledgements}

We thank Heritage Saint-Bernard, the non-profit organisation that administers the refuge faunique Marguerite-D'Youville, for its support. We are also grateful to the Laboratoire de lutte biologique of UQAM for their helpful comments on previous drafts of the manuscript.

\section{REFERENCES}

Alhmedi A, Haubruge É, Francis F (2010) Intraguild interactions implicating invasive species: Harmonia axyridis as a model species. Biotechnol Agron Soc Environ. 14: 187-201.

Alyokhin A, Sewell G (2004) Changes in a lady beetle community following the establishment of three alien species. Biol Invasions 6: 463-471.

Berthiaume R, Hébert C, Cloutier C (2000) Predation on Mindarus abietinus infesting balsam fir grown as Christmas trees: the impact of coccinellid larval predation with emphasis on Anatis mali. BioControl 45: 425-438.

Brown MW, Miller SS (1998) Coccinellidae (Coleoptera) in apple orchards of Eastern West Virginia and the impact of invasion by Harmonia axyridis. Ent News 109: 143-151.

Brown MW (2003) Intraguild responses of aphid predators on apple to the invasion of an exotic species, Harmonia axyridis. BioControl 48: 141-153.

Coderre D, Lucas É, Gagné I (1995) The ocurrence of Harmonia axyridis (Pallas) (Coleoptera : Coccinellidae) in Canada. Can Ent 127: 609-611.

Cottrell TE, Yeargan KV (1998) Intraguild predation between an introduced lady beetle, Harmonia axyridis (Coleoptera: Coccinellidae), and a native lady beetle, Coleomegilla maculata (Coleoptera: Coccinellidae). J Kans Ent Soc 71: 159-163.

Evans EW, Youssef NN (1992) Numerical responses of aphid predators to varying prey density among Utah alfalfa fields. J Kans Ent Soc 65: $30-38$.

Evans EW (2000) Morphology of invasion: Body size patterns associated with establishment of Coccinella septempunctata (Coleoptera: Coccinellidae) in western North America. Eur J Ent 97: 469-474.
Evans EW (2004) Habitat displacement of North American ladybirds by an introduced species. Ecology 85: 637-647.

Finlayson CJ, Landry KM, Alyokhin AV (2008) Abundance of native and non-native lady beetles (Coleoptera: Coccinellidae) in different habitats in Maine. Ann Ent Soc Am 101: 1078-1087.

Gardiner MM, Landis DA (2007) Impact of intraguild predation by adult Harmonia axyridis (Coleoptera: Coccinellidae) on Aphis glycines (Hemiptera: Aphididae) biological control in cage studies. Biol Control 40: 386-395.

Gardiner MM, Landis DA, Gratton C, DiFonzo CD, O’Neal M, Chacon JM, Wayo MT, Schmidt NP, Mueller EE, Heimpel GE (2009) Landscape composition influences patterns of native and exotic lady beetle abundance. Divers Distrib 15: 554-564.

Gordon RD (1985) The Coccinellidae (Coleoptera) of America North of Mexico. J N Y Ent Soc 93: 1-912.

Harmon JP, Stephens E, Losey J (2007) The decline of native coccinellids (Coleoptera: Coccinellidae) in the United States and Canada. J Insect Conserv 11: 85-94.

Héritage Saint-Bernard (2004) Guide de l'île Saint-Bernard : À la découverte du refuge faunique Marguerite-D’Youville.

Hironori Y, Katsuhiro S (1997) Cannibalism and interspecific predation in two predatory ladybirds in relation to prey abundance in the field. Entomophaga 42: 153-163.

Hoogendoorn M, Heimpel GE (2002) Indirect interactions between an introduced and a native ladybird beetle species mediated by a shared parasitoid. Biol Control 25: 224-230.

Kajita Y, Yasuda H, Evans EW (2006) Effects of native ladybirds on oviposition of the exotic species, Adalia bipunctata (Coleoptera: Coccinellidae). Jap Appl Ent Zool 41: 57-61.

Kajita Y, Evans EW (2010) Alfalfa fields promote high reproductive rate of an invasive predatory lady beetle. Biol Invasions 12: 2293-2302.

Koch RL, Hutchison WD, Venette RC, Heimpel GE (2003) Susceptibility of immature monarch butterfly, Danaus plexippus (Lepidoptera: Nymphalidae: Danainae), to predation by Harmonia axyridis (Coleoptera: Coccinellidae). Biol Control 28: 265-270.

Koch RL, Galvan TL (2008) Bad side of a good beetle: The North American experience with Harmonia axyridis. BioControl 53: 23-35.

Labrie G, Lucas É, Coderre D (2006) Can developmental and behavioral characteristics of the multicolored Asian lady beetle Harmonia axyridis explain its invasive success? Biol Invasions 8: 743-754.

Labrie G, Coderre D, É Lucas (2008) Overwintering strategy of multicolored Asian lady beetle (Coleoptera: Coccinellidae): cold-free space as a factor of invasive success. Ann Ent Soc Am 101: 860-866.

Larochelle A (1979) Les Coléoptères Coccinellidae du Québec. Cordulia (Suppl.) 10: 1-111.

Lodge DM (1993) Species invasions and deletions: community effects and responses to climate and habitat changes. In: Kareiva PM, Kingsolver JG, Huey RB, Sunderland, MA: Sinauer (eds) Biotic Interactions and Global Change. pp 87-367.

Lucas É, Vincent C, Labrie G, Chouinard G, Fournier F, Pelletier F, Bostanian N, Coderre D, Mignault M-P, Lafontaine P (2007a) The multicolored Asian ladybeetle Harmonia axyridis in Quebec agroecosystems ten years after its arrival? Eur J Ent 104: 737-743.

Lucas É, Labrie G, Vincent C, Kovach J (2007b) The multicolored Asian ladybeetle, Harmonia axyridis-beneficial or nuisance organism? In: Vincent C, Goettel M, Lazarovitz G (eds) Biological control: a global perspective. CABI Publishing, UK.

Michaud JP (2002) Biological control of Asian citrus psyllid, Diaphorina citri (Hemiptera: Psyllidae) in Florida: a preliminary report. Ent News 113: 216-222. 
Musser FR, Shelton AM (2003) Factors altering the temporal and within-plant distribution of coccinellids in corn and their impact on potential intraguild predation. Environ Ent 32: 575-583.

Pell JK, Baverstock J, Roy HE, Ware L et Majerus MEN (2008) Intraguild predation involving Harmonia axyridis: A review of current knowledge and future perspectives. BioControl 53: 147-168.

Phoofolo MW, Obrycki JJ (1998) Potential for intraguild predation and competition among predatory Coccinellidae and Chrysopidae. Ent Exp Appl 89: 47-55.

Pimentel D, Lach L, Zuniga R, Morrison D (2000) Environmental and economic cost of nonindigenous species in the United States. Bioscience 50: 53-65.

Reitz SR, Trumble JT (2002) Competitive displacement among insects and arachnids. Annu Rev Ent 47: 435-465.

Sakai AK, Allendorf FW, Holt JS, Lodge DM, Molofsky J, With KA, Baughman S, Cabin RJ, Cohen JE, Ellstrand NC, McCauley DE, O’Neil P, Parker IM, Thompson JN, Weller SG (2001) The population biology of invasive species. Ann Rev Ecol Syst 32: 305-332.

Sakuratani Y, Marsumoto Y, Oka M, Kubo T, Fuji A, Uotani M, Teraguchi T (2000) Life history of Adalia bipunctata (Coleoptera: Coccinellidae). Jap J Ent 97: 555-558.

SAS Institute (2007) JMP In, version 7.0.1 SAS Institute Inc., Cary, North Carolina.

Simberloff D (1989) Which insect introductions succeed and which fail? In: Drake JA, Mooney HA, di Castri F, Groves RH, Kruger FJ, Rejmánek M, Williamson M (eds) Biological invasions: a global perspective. Wiley, Chichester, UK, pp 61-75.
Simberloff D, Stiling P (1996) Risks of species introduced for biological control. Biol Conserv 78: 185-192.

Snyder WE, Clevenger GM, Eigenbrod SD (2004) Intraguild predation and successful invasion by introduced ladybird beetles. Oecologia 140: 559-565.

Soares AO, Borges I, Borges PAV, Labrie G, Lucas É (2007) Harmonia axyridis: What will stop the invader? Biocontrol 53: 127-145.

Tilman D (1997) Community invasibility, recruitment limitation, and grassland biodiversity. Ecology 78: 81-92.

Turnock WJ, Wise IL, Matheson FO (2003) Abundance of some native coccinellines (Coleoptera: Coccinellidae) before and after the appearance of Coccinella septempunctata. Can Ent 135: 391-404.

Usher MB (1988) Biological invasions of nature reserves: a search for generalisations. Biol Conserv 44: 119-135.

Vitousek PM, Di Antonio CM, Lloyd L Loope LL, Rejmánek M, Westbrooks R (1997) Introduced species: a significant component of human-caused global change. $\mathrm{N} \mathrm{Z} \mathrm{J} \mathrm{Ecol} \mathrm{21:}$ $1-16$.

Ware RL, Majerus MEN (2007) Intraguild predation of immature stages of British and Japanese coccinellids by the invasive ladybird Harmonia axyridis. BioControl. doi:10.1007/ s10526-007-9135-8.

Williamson M (1996) Biological invasions. Chapman and Hall, London.

Yasuda H, Evans EW, Kajita Y, Urakawa K, Takizawa T (2004) Asymmetric larval interactions between introduced and indigenous ladybirds in North America. Oecologia 141: 722-731. 